\title{
Efficiency of Commercial Banks in East Africa: A Non Parametric Approach
}

\author{
Gwahula Raphael $^{1}$ \\ ${ }^{1}$ School of Accounting, Dongbei University of Finance and Economics, Dalian, P. R China \\ Correspondence: Gwahula Raphael, School of Accounting, Dongbei University of Finance and Economics, Post \\ Code 116025, Hei Shi Jiao, Dalian, P. R China. E-mail: gwahular@gmail.com
}

Received: November 6, 2012 Accepted: January 14, 2013 Online Published: January 20, 2013

doi:10.5539/ijbm.v8n4p50 URL: http://dx.doi.org/10.5539/ijbm.v8n4p50

\begin{abstract}
This paper employs Data Envelopment analysis (DEA) to estimate the relative efficiency of selected 58 commercial banks operating within the East African Community, namely Tanzania, Kenya, Uganda, Rwanda and Burundi. From 2008 to 2011. The estimated results shows sharp decline of Technical efficiency from 0.81 (2008) to 0.56 (2009) there after showing an increasing trend of technical efficiency in 0.73 (2011). Under BCC and CCR model the number of efficient commercial banks which shows in their four years with the score 1, were Tanzania (42), Kenya (66), Uganda (61), Rwanda (11) and Burundi (21). The findings show that most commercial banks in east Africa are operating under a decreasing return to scale. Therefore inefficient utilization of input resources (technical inefficiency) could be one of the reasons for the inefficiency of commercial banks in East Africa; therefore banks should make use of underutilized resources and reduce operating expenses to be relatively efficient in the production frontier.
\end{abstract}

Keywords: data envelopment analysis, efficiency, East African Countries (EAC)

\section{Introduction}

The importance of commercial banks to the socioeconomic development of some countries cannot be ignored, from both developed and developing countries banks have shown a significant role in the development and growth of economy by insuring prudent allocation of resources as well as their efficient utilization. In East Africa since financial reform in early 1990s credit allocation to the private sector has increased dramatically compared to the past where government borrowing from banking system was quite high which results do decline of resources which could otherwise be borrowed to private sectors. Credit policy from East African central banks has been directed to improve government fiscal balance by reducing borrowing from the banking system. For example in Tanzania 2010 commercial banks credits extended to private sector was TSh 6,029.4 billion (2010) compared to Tsh4, 805.8 billion as the end of December 2009 equivalent to an increase of 25.5 percent, credit were directed to various economic activities such as personal loans, business activities and transportation and communication (MOF 2010) on another hand annual growth in credit to private sector during 2002-2010 averaged 28 percent in Uganda, 32 percent in Tanzania, and 15 percent in Kenya. This has resulted to increase to private sector share per GDP from 8 percent to 16 percent in Uganda, 6 to 16 percent in Tanzania and 25 to 33 percent in Kenya (IMF 2012). Despite the increasing trend of allocation of credits to the private sector, the interest rate spread is still very high, even if banking regulation in east Africa has permitted the penetration of foreign banks to operate in the economy.

Another problem facing East African countries is access to financial services. The access to financial services is still very low especially for the huge population in the rural areas. For example in Tanzania alone one in Six Tanzanians has access to financial services from formal institutions, this is to say over half of the population of Tanzania is excluded from financial services, looking at the economy of Tanzania whereby $80 \%$ of people are engaged in agricultural activity and are contributing over $56 \%$ of the economy. This situation is similar to other members of east African countries for example less than a third of the population in Uganda, Rwanda, and Burundi do not have proper access to financial services. One of the reasons for this situation is that the majority of banks and financial institutions are more commercial targeting commercial traders than farmers; similarly the majority of people in rural areas lacks bank knowledge, also poor infrastructure discourage commercial banks and financial institutions to operate in rural areas. To reduce the severity of the problem, the micro institutions 
operating in rural areas have been used to reduce the intensity of the problem, however these micro financial institutions are not properly regulated, and in most cases they are running on their own.

Few studies in East Africa have directed their attention in analyzing the relative efficiency of commercial banks within country states. To the best of researcher knowledge no cross sectional studies have been done so far to analyze efficiency of commercial bank using non parametric approach. Apart from IMF working paper by Sarah and Matthew (2010) whose main focus was to investigate Bank competition within the East African community using different approaches. Therefore the relative efficiency of different banks operating within the East African community is still not known and therefore calls for more literatures.

Therefore this paper intends to measure the efficiency of commercial banks operating within the East African community, using the BCC model and the CCR model of Data Envelopment Analysis (DEA) for the purpose of classifying banks as relative efficient and less efficient. By focusing on intermediation efficiency, this paper will have significant contribution to policy makers, academician, bank regulators as well as management studying trends in commercial bank efficiency. Secondly this paper will provide an indication of success or failure by which the performance of individual banks and the industry in general can be measured.

Therefore our work is organized as follows; section two reviews structure of banking in East Africa, section three reviews literature on studies of bank efficiency, followed by a description of the methodology and data specification used in the study, The Data Envelopment analysis is used to estimate the relative efficiency of different banks under study. The estimated results of East African commercial banks are then presented. The paper concludes by summarizing the main findings and provides some suggestions for policy implication and future research.

\section{Structure of Banking System in East Africa}

Five countries under study forms East African countries, these countries are such as Tanzania, Uganda, Kenya, Rwanda, and Burundi. The East African community (EAC) is the regional Intergovernmental organization of the republics of Kenya, the united republic of Tanzania, Republic of Rwanda and Republic of Burundi with its headquarter in Arusha Tanzania

The structure of the banking system within the member state is as follows; the banking sector in Kenya includes 43 commercial banks, among them 12 is foreign banks and has established 14 subsidiaries in neighboring countries. The banking system in Tanzania has grown since reform in the early 1990s, but remains relatively small and dominated by the top tier of large domestic banks and foreign banks. Currently there are 33 commercial banks in Tanzania, among which 16 are foreign banks, in terms of ownership structure; Government ownership is limited to four smaller fully-owned banks and minority stakes in the three largest domestic banks. The top tier mainly caters to a small group of large corporate, which is often represented up to 70 percent of banks` loan portfolios. While the banking system in Uganda has expanded significantly since a memorandum on licensing new banks was lifted in 2005, eight new banks have been licensed since 2005, bringing a total of 22commercial banks, including 14 foreign banks, operating in Uganda. In Rwanda there about 12 commercial banks operating in Rwanda including three foreign banks, on the other hand in Burundi there are seven and two financial establishments with total asset representing 54 percent of GDP. Privately owned banks account for 73 percent of assets and 80 percent of deposits; the government remains the major shareholder in two financial establishments specializing in housing and development

\section{Literature Review of Bank Efficiency}

This section reviews the relevant literature on bank efficiency, with much emphasis on studies of sub-Saharan Africa as well as cross country studies. Efficiency in general, is a measure of deviation between actual performance and desired performance; efficiency can therefore be defined in terms of orientation i.e. Input oriented as well as an output oriented measure of efficiency. An output oriented measure of efficiency compares the observed output with maximum output possible for a given input level; alternatively an input oriented measure of efficiency compares the observed level of input with the minimum input that could produce the observed level of output. A number of studies have sought to measure the efficiency of financial institution, to identify the factors that contribute to the efficiency of the financial institutions and to recommend ways to attain the peer group efficiency levels (Berger, A.N, Hunter, W.C and Time, S.G 1993)

The efficiency of the financial system can be noticed when the lending rate and the deposit rate is very low i.e. the efficiency within the banking industry occur when the interest rate spread is low. When this happens it will stimulate both greater loan demands for industrial investment as well as greater mobilization of savings through the banking system. But this situation is different with commercial banks operating SSA (Sub Saharan Africa) 
particularly Banks in most East African countries which are operating with relatively wide spreads. Studies in banking efficiencies have pointed at operating inefficiencies caused by high operating costs, default risks as well as financial market structure are some of possible sources that need to be investigated.

Most studies of bank efficiency have directed their attention into two major aspects namely production approach as well as intermediation approach. Under intermediation approach, financial intermediaries are regarded as institutions that convert and transfer financial assets between surplus unit and deficit unit (Aikael, 2008, Millas and Noulas, 1996) and production approach refers to the financial institution as the producer of services to account holder, meaning that they perform transactions on deposit, accounts and process documents such as loan (Ferrier and Lovell, 1990). Efficiency in banking has been studied using different methods (both parametric and non parametric methods). Berger and Humphrey (1997) provide an outstanding survey that summarizes the main conclusion of 130 financial institutions, in 21 countries employing different efficiency estimation methods. The major findings were that various efficiency methods do not necessarily yield consistent results and suggest the ways that these methods might be improved to bring about findings that are more consistent, accurate and useful. This study will employ the non Parametric Method (DEA) to analyze relative efficiency of East African commercial banks.

\subsection{Literature of Bank Efficiency in Sub Saharan Africa}

Study of efficiencies of commercial banks in Sub Saharan Africa (SSA) is very important because most of these countries have similar regulatory conditions and macroeconomic conditions; the following are some of key studies on bank efficiency in SSA.

Kiyota (2009) provides a comprehensive banking sector efficiency analysis of sub Saharan African countries (SSA). The study employs two stage analysis in examination of profit efficiency and cost efficiency of commercial banks namely stochastic frontier approach and Tobit regression. The stochastic frontier approach was utilized to estimate profit efficiency and cost efficiency, whereas Tobit regression was employed to provide cross country evidence of the influence of environmental factors on efficiency Sub Saharan African commercial banks. The results of the study indicate that foreign banks outperform domestic banks, more over consistent with the agency postulates, banks with higher leverage or lower equity were found to be associated with higher profit efficiency, however in terms of bank size, smaller banks were found to be more profit efficiency whereas medium size and larger banks were cost efficient. A similar approach was applied in Namibia by Ikhide (2008) in which the findings revealed the existence of economies of scale in Namibian commercial banks which can be exploited by banks expanding their scale of their operation. The other study in the same country is the study by Jonathan (2005) whose the main concern was investigating factors influencing the efficiency in the Namibian banking system, the findings of this study revealed industry specific characteristics such as concentration has more influence on bank efficiency. Within a similar geographical environment is the study by Antony Musonda (2008); using a single stage maximum likelihood estimation procedure applied to a stochastic frontier cost function, revealed Zambian banks were on average inefficient in order of $11.4 \%$, in their analysis foreign banks were found to be more efficient than domestic banks, especially the state banks.

Other studies were performed in some countries of East Africa, the study of Anne W. Kamau (2011) as well as the study by Aikaeli (2008). Both studies used DEA approach to obtain estimated efficiency, Anne Kamau (2011) investigated the efficiency and productivity of banking sector in Kenya post liberalization using DEA ,the major findings of the study indicate most banks performed fairly with more chance of improvement, the estimated scores were not less than 40 percent during the year of study, more over the results revealed foreign banks were more efficient than domestic banks, where as in local category local private are more efficient than local public, in terms of size large sized banks were found to be relatively efficient than small and medium sized banks. On other hand Aikaeli (2008) investigated the efficiency of commercial banks in Tanzania, utilizing secondary time series of the Tanzania banking sector, the paper examines technical, scale and cost efficiency of banks, similarly Data Envelopment Analysis (DEA) model was applied to derive efficiency estimates of the banks. In contrast to the above study in terms of ownership the study found foreign banks to be more efficient compared to the counterpart medium and small banks.

With no exception to West Africa the study by Soboddu, O and Akiedo (1998), applied similar approach Data Envelopment Analysis (DEA), to investigate bank performance and supervision in Nigeria during transition and deregulated economy. The study found that banking industry intermediation efficiency declined significantly during the years immediately following the adoption of deregulation with slight improvements noticed only in recent times. The results conclude that this may be the effect of inconsistent policies to which the sector was subjected during this period. Moreover the study shows private and government banks differ in their technical 
efficiency, the average efficiency measures are higher for private banks than the government's banks.

Another study in Sub Saharan Africa is the study by Victor Murinde and Moses Tefula (2002) using different approaches such as Translog stochastic cost and profit frontier approach. Study measurement and determinant of $\mathrm{X}$-Inefficiency in commercial Banks in sub Saharan Africa found the degree of cost inefficiency is exacerbated by bad loans, high capital ratio and financial liberalization. Moreover it is shown the large banks are more efficient and the level of foreign bank penetration reduces $\mathrm{x}$ - inefficiency. A similar approach was applied by, Ncube (2009) in South African banking sector efficiency whose main focus was on cost and profit efficiency of banks in South Africa, Applying stochastic frontier model, the paper examined the cost and profit efficiency of small and four large banks. Results indicated that over the period of study (2000-2005) South African banks significantly improved their cost efficiencies and no significant gains and profitability fronts. The results also indicated that there is a weak positive correlation between cost and profit efficiency of South African banks. In Addition that most cost efficient banks were also most profit efficient. A regression analysis of cost efficiency banks size suggests a negative relationship with cost efficiency declining with the increasing bank size, the findings contradict with Molynuex and Thornton (1992).

Most of the studies above aimed at analyzing by comparing the relative efficiency between different groups of banks operating in respective countries, we have seen groups such as foreign and domestic, small, medium and large peers within the banking industry. However the cross country analysis of bank efficiency among the member states of East Africa is relatively lacking in the literature and there hasn 't been any intensive work being done on cross country efficiency comparisons for banks in East Africa.

\subsection{Cross Country Studies of Bank Efficiency}

Most cross country studies assume homogeneity within the countries under study, meaning that banks in different countries can access the same banking technology, by assuming common production frontier for all countries. This also can be applied to most countries in East Africa as production technology is quite similar among countries. Different from other researchers, our major focus is to analyze relative efficiency of sampled commercial banks operating in this part of the world. The following are some of cross country studies across different countries.

Samy et al (2007) used Data Envelopment Analysis (DEA) to evaluate bank efficiency in MENA countries from 1993 to 2006 the major findings indicated that despite similarities in the process of financial reform the efficiency of sampled commercial banks varies substantially across the market. In this study Morocco and Tunisia outperformed Egypt and Jordan. While the difference in banking technologies was observed to be crucial in explaining differences in efficiency. In a similar situation, Allen Marius (2010) analyzed the efficiency of the main banks in Romania, The Czech republic and Hungary for the period 2000-2006 by using frontier analysis and for the estimation of efficiency of banking they used Data Envelopment Analysis (DEA). The results of their analysis indicated the banks in the three East -European countries reach a low level of technical efficiency and cost efficiency, especially the ones in Romania, and that the main factors influencing the level of banking efficiency in these countries where the quality of an asset, bank size, annual inflation rate, banking reform and interest rate liberalization. The other study in the same region is the study by Singh et al, (2010) using Non Parametric method, attempted to estimate the efficiency of the top 300 Asian Pacific Banks, as ranked by Asian bankers through a cross section study. The empirical finding indicates that only 22 of 300 banks were operating at an efficient level. In general, the overall technical efficiency and scale efficiency were higher in bank groups in Newsland and Australia, while the Philippines bank groups were found to have the lowest estimates; the study revealed the main sources of inefficiency amongst 300 banks are dominated by ineffective utilization of resources rather than economies of scale.

\section{Research Methodology}

Efficiency analysis is essential for evaluation bank performance, financial indicators are still important analytical instrument, and bank owners and potential customers use them to compare and evaluate the performance of the banks. That is why banks need to pay particular attention to the value of traditional indicators if they want to create a positive image and to be perceived positively by the general public, these indicators are such as profitability rates, margin rates, weighted result rates and employment efficiency rates. The bank financial reports such as balance sheet, profit and loss accounts or, less frequently cash flow accounts are used to assess the efficiency of the indicators the disadvantages of financial ratios as being that they are only meaningful when used with suitable benchmark, which may be difficult to establish. Therefore there is a need for a more flexible way of expressing bank's financial position. This paper will focus on one of the advanced methods of measuring efficiency. The advanced methods are such as. 


\subsection{Econometric Approach}

Two econometric techniques have been applied in the literature to evaluate the efficiency of the organization ranging from operations, cost as well as profit efficiencies; these are parametric technique and non parametric technique

\subsubsection{Parametric Techniques}

The parametric technique includes three categories:

Stochastic Frontier Approach (SFA); proposes that the observed bank costs may deviate from the cost frontier either because of inefficiency or random fluctuation. SFA posits a composed error model where inefficiencies are assumed to follow an asymmetric distribution, usually the half normal, while the random errors follow a symmetric distribution usually the standard normal (Berger \& Humphrey, 1997). The following are parametric techniques Distribution Free Approach (DFA); this method assumes that there is core inefficiency for a firm over time. The core inefficiency is distinguished from random error by assuming that, core inefficiency is persistent over time, while random errors tend to cancel each other out in the course of time (Berger \& Humphrey, 1997) on another hand The Thick frontier Approach (TFA); specifies a functional form and assumes that deviations from predicted performance value within the highest and lowest performance quartiles of observation represent random error, while deviations in predicted performance between the highest and lowest, represent inefficiencies. TFA itself does not provide exact point estimates of efficiency of individual firms but is intended instead to provide an estimate of the general level of overall efficiency (Berger \& Humphrey, 1997)

\subsubsection{Non-Parametric Techniques}

There are two linear mathematical programming techniques that have been used in many efficiency studies; One of the approaches is Data Envelopment Analysis (DEA); which is the linear programming technique where the set of best practices or frontier observations are those for which no other decision making unit or linear combination of units has as much or more of every output (given inputs or as little or less of every input (given output). DEA does not require the explicit specification of the form of the underlying production relationship (Berger \& Humphrey, 1997). Other benefits are such as it can be used to uncover relationship that remain hidden for other methodologies, the source of inefficiency can be analyzed and quantified for every evaluated decision unit. On other hand Free Disposable Hull (FDH) approach was found to be a special case of the DEA model where the points with lines connecting the DEA vertices are not included in the frontier (Tulkens, 1993). Despite the advantages of the above non parametric methods there are some weaknesses. The major weakness of these nonparametric approaches is that they generally assume that there is no random error such as no measurement error, no inaccuracies created by accounting rules that would make measured outputs and inputs deviate from economic output and inputs as well as no luck that temporarily gives a decision making unit better measured performance one year from the next (Berger \& Humphrey, 1997). Moreover DEA also suffers from a self -identifiers and near-self identifiers problem. When imposing constraints like quality control and control variables in the model, some firms may be self identified as $100 \%$ efficient simply because no other firms or linear combination of firms are comparable in some dimensions. When there are a small number of observations relative to the number of inputs, outputs and other constraints, it is difficult for a large proportion of the observations to match in all dimensions (Bauer et al 1998). We focus our measures of efficiency to a work by Debreu (1951) and Farrell (1957) and considering its extension to Charnes -Cooper-Rhodes (CCR) (1978) and the Banker- Charnes-Cooper (BCC) (1984) model to evaluate relative efficiency of East African banks.

\section{CCR Model}

The mathematical illustration of the basic DEA model is traceable to Charnes Cooper and Rhodes (1978) and is referred as to as CCR model. If no banks (as DMUs) convert the same m inputs into the same S output and the get bank uses a m-dimensional input vector, $\mathrm{Xij}(\mathrm{i}=1,2 \ldots, \mathrm{m})$ to produce an S-dimensional

Problem solved for each bank is expressed as:

$$
\text { Maximize } \quad h_{o}=\frac{\sum_{r=1}^{s} u_{r} y_{r o}}{\sum_{i=1}^{s} v_{i} x_{i o}}
$$

Subject to the constraints 


$$
\begin{gathered}
\frac{\sum_{r=1}^{s} u_{r} y_{r j}}{\sum_{i=1}^{s} v_{i} x_{i j}} \leq 1 ; j=1,2, \ldots, n \\
\frac{u_{r}}{\sum_{i=1}^{m} v_{i} x_{i o}} \succ \varepsilon ; r=1 . ., s \text { and } \frac{v_{i}}{\sum_{i=1}^{m} v_{i} x_{i o}} \succ \varepsilon ; i=1 . ., m, \varepsilon \succ 0
\end{gathered}
$$

The model measures relative performance of the decision making unit (DMUs). These can be individual units or a group of unit pairs. There are $n$ DMUs which are $j=1,2 \ldots n$. In the model, $Y_{r j}>0$ and $X_{i j}>0$ represent the observed amount of rat output and its input of the $j$ th DMU. $\mathrm{DMU}_{0}$ efficiency score is $0 \leq \mathrm{h}_{0} \leq 1$ as regards the constraints. $\varepsilon>0$ is a non Archimedean constant that is smaller than any positive valued real number for $\mathrm{h}_{0} . U_{r}$ and $V_{i}$ represent visual multipliers obtained by solving the maximization problem. In equation 1 the numerator represents a set of desired output and the denominator represents a set of inputs. Visual output, $y_{o}=\Sigma_{u_{r}}^{*} y_{r o}^{*}$ is summed over $\mathrm{r}=1,2 \ldots \mathrm{S}$. Visual input, $\mathrm{X}_{0}=$ is summed over $\mathrm{i}=1,2 \ldots \mathrm{m}$. The obtained $\mathrm{h}_{0} *=\mathrm{Y}_{0} / \mathrm{X}_{0}$, is an efficiency score which satisfies $0 \leq \mathrm{h}_{0} * \leq 1$. When $\mathrm{h}_{0} *<1$. When $\mathrm{h} 0 *=1$ represents full (or 100 percent) efficiency and $\mathrm{h}_{0} *<$ 1 represent some relative inefficiency. The CCR DEA model is represented as a dual problem of maximization linear programming, such as

Minimize

$$
\Phi_{0}-\varepsilon\left[\sum_{i=1}^{m}{S_{i}^{-}}^{-}+\sum_{r=1}^{s} S_{r}^{+}\right]
$$

Subject to

$$
0=\Phi_{0} x_{i o}-\sum_{j=1}^{n} x_{i j} \lambda_{j}-s_{i}^{-} \text {and } y_{r o}=\sum_{j=1}^{n} y_{r j} \lambda_{j}-s_{r}^{+}
$$

Where $\Phi_{0}$ is efficiency score of a particular decision mitking unit $\left(\mathrm{DMU}_{0}\right)$ in $\mathrm{t} . \mathrm{ms}$ of dual solution. $\lambda \mathrm{j}$ is a vector of constants while $S_{i}^{-}$is a vector of non negative slack associated with inputs inequalities and $S_{i}^{+}$is a vector of non negative slack associated with input inequalities. Because equation (2) has a finite optimal solution, from the duality theory of linear programming we have

$$
h_{0}^{*}=\Phi_{0}^{*}=\varepsilon\left(\sum_{i=1}^{m} s_{i}^{+^{*}}+\sum_{r=1}^{s} s_{r}^{+^{*}}\right)=\sum_{r=1}^{s} u_{r}^{*} y_{r o}
$$

This is used to estimate efficiency scores.

\section{BCC model}

The former basic model was later developed by Banker, Charnes and Cooper (1984) widened The CCR model to account for variable Return to scale (VRS) by adding the following constraints.

Minimize

$$
\Phi_{0}-\varepsilon\left[\sum_{i=1}^{m} s_{i}^{-}+\sum_{r=1}^{s} s_{r}^{+}\right] \text {Subject to }
$$




$$
\begin{gathered}
0=\Phi_{0} x_{i o}-\sum_{j=1}^{n} x_{i j} \lambda_{j}-s_{i}^{-} \\
y_{r o}=\sum_{j=1}^{n} y_{r j} \lambda_{j}-s_{r}^{+} \quad \text { and } \quad 1=\sum_{j=1}^{n} \lambda_{j} .
\end{gathered}
$$

$0 \leq \lambda_{j}, s_{i}^{-}, s_{r}^{+}$for $i=1,2 \ldots, m ; \mathrm{r}=1,2 \ldots, \mathrm{s} ; j=1,2 \ldots \ldots \ldots \ldots, n$ we notice now that $\lambda_{j} s$ are restricted to sum up to one which eliminates the constraints in CCR that DMU must be scale efficient for it become technical efficient. Models (2) to (4) are estimated for DEA efficiency scores ranges between 0 and 1 . By adding the above constraints a convex hull of intersecting planes envelop the data points more tightly than the former basic CCR model (CRS) conical hull and thus provide technical efficiency scores which are greater than or equal to those obtained using the CRS model.

\subsection{Data}

All of the data required for this study were obtained from the Bank Scope database which provides data for a large number of banks in many countries of the world in the form of balance sheet income statements, various ratios, and ownership information from 2007 to 2011. This database is updated monthly and the latest issue of bank scope database used in this study was September 2012. But the data were supplemented by annual reports obtained from individual banks' websites. The total of 58 commercial banks was sampled for analysis; selection was based on availability of data.

\subsection{Selection of Inputs and Outputs}

Based on the literatures there is no clear point on the selection of inputs and output, it was found that the selection of inputs and output follows the factors of production function namely capital, labor and land. There are two approaches in studying banking efficiency namely production approach and intermediation approach.

The production approach addresses physical inputs, such as capital and labor and treats a bank as firms producing different deposits and loan accounts. Banks deal with transactions and document for its customers who own these accounts. The number of accounts and transactions are regarded as the best measures of the bank output; to some extent this is not practical. In practice, the number of deposit and loan account is usually used as the measure of bank output rather than the detailed in transaction and documents (Ferrier and Lovell, 1990)

The other approach is an intermediation approach (Sealey and Lindley, 1997), treats banks as financial intermediaries that channels funds between depositors and creditors in the bank production process, the value of bank loans and investment is thought as output, while labor, deposits, and capital are treated as inputs. This approach is distinguished from the production approach by adding deposits two inputs, which result in consideration of both operating and interest costs (Allen, L and Rai, A., 1996), Drake and Hall (2003) Fries and A. Taci, (2005).

By carefully examining the literature above we decided to follow intermediation approach, commonly used by many authors. We used different combination of input and output such as Deposit, interest expenses, operating expenses, loan, investment, interest income and noninterest income. The first three were treated as inputs while the last four were treated as output. The selection of the above input and output was also supported by Miller and Noulas 1996, Hassan, et al 2009, Singh, et al 2008, Siems, 1992, Yue, 1992 and Barr, R.S., L. M. Seaford and T.F Siems, 1993. We used Input orientation when running DEA model under both Constant Return to Scale (CRS) and Variable Return to Scale (VRS) assumptions, Technical efficiency and pure technical efficiency scores were obtained which was used to compute Scale efficiency by dividing technical efficiency by pure technical efficiency.

The table 1 of the appendix presents, the descriptive statistics of variables involved in this study, the values are in million of respective country currencies, i.e. Burundi and Rwanda the currency is indicated in Francs, while Tanzania, Uganda and Kenya the currency is indicated in Shillings.

\section{Results}

The following section discusses the empirical findings of both CCR and BCC model. Appendix 2 and 3 of the presents the empirical findings based on Constant Return to scale under the CCR model. Average Technical efficiency within the selected banks of the East African community ranges from 0.81 (2008) to 0.73 (2011). There were sharp decline of technical efficiency from 0.81 (2008) to 0.56 (2009) there after showing an 
increasing trend of technical efficiency in 0.73 (2011). Generally the results show that banks are using more resources than what they are producing. Selected Banks were supposed to use 81 percent to 51 percent of resources available for them to be efficient without compromising the output level under CRS.

Appendix 3 presents the empirical findings under VRS (BCC Model). Mean efficiency of East African commercial banks ranges from to 0.86 (2008) to 0.81 (2011). Also the selected banks were supposed to use a range 86 percent to 81 percent of available to maintain the same level of out. Therefore commercial banks were supposed to reduce input resources by 19 percent 2008, 43 percent 2009, 27 percent 2010 and 26 percent 2011 under CRS for them to be technically efficient without affecting the outputs. On other hand commercial banks were supposed to reduce the input level by $16 \%$ (2008), 31\% (2009), 18\% (2010) and 9\% (2011). The mean efficiency summary is shown in the table 1 below.

Table 1. Mean efficiency estimates

\begin{tabular}{lccc}
\hline Year & Mean $(\mathrm{CRS})$ & Mean $(\mathrm{VRS})$ & Mean $(\mathrm{SE})$ \\
\hline 2008 & 0.814115828 & 0.859174966 & 0.945661724 \\
2009 & 0.567641879 & 0.694829948 & 0.836574586 \\
2010 & 0.727035586 & 0.823881017 & 0.886684672 \\
2011 & 0.731391086 & 0.807615397 & 0.911171569 \\
\hline
\end{tabular}

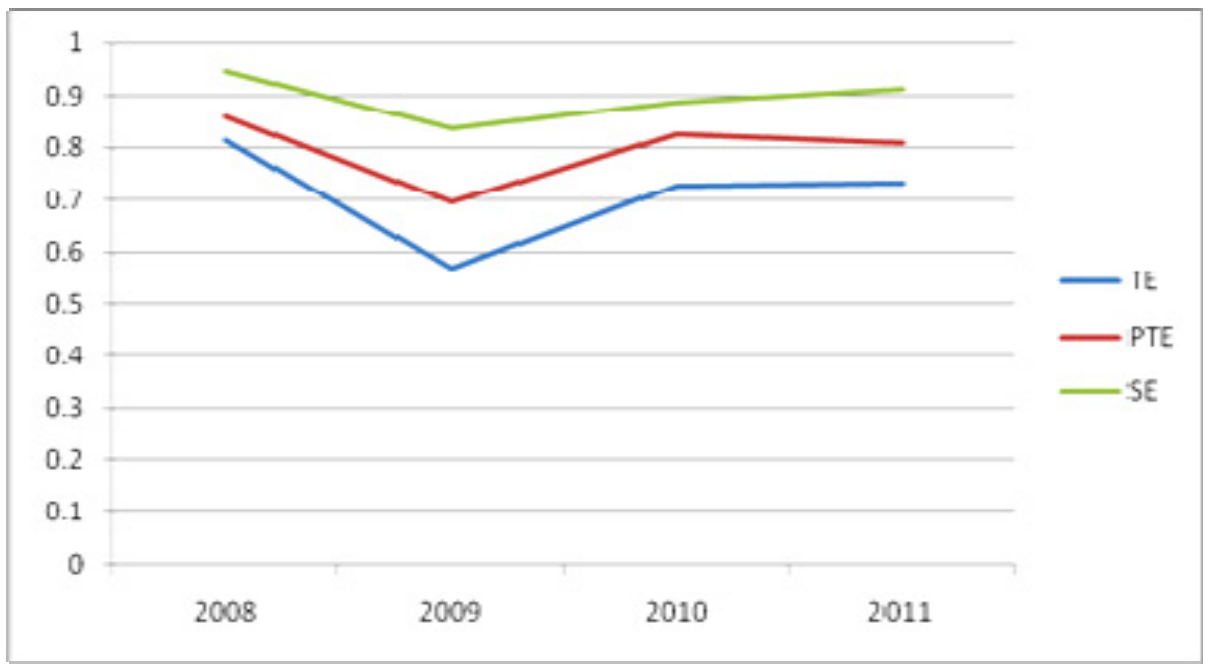

Figure 1. Efficiency trend of commercial banks

The efficiency trend indicates most of the commercial banks in East Africa were inefficient in the year 2009, with technically efficient being the lowest compared with PTE and SE, thereafter increased sharply to reach $88 \%$ and $91 \%$ by the year 2010 and 2011 respectively. This is to say the inefficiency of the East African commercial was more concerned with poor utilization of input resources and not the scale of operations.

Table 2 indicates the average efficiency results country wise including the number of selected efficient commercial banks with Kenya indicating more efficient commercial banks when compared to the other commercial banks within the EAC countries. The results show a significant relationship with socioeconomic factors such as level of economic development population size, regulatory framework and level of institutional development. Under BCC and CCR model the number of efficient commercial banks which shows in their for four years to score 1, were Tanzania (42), Kenya (66), Uganda (61), Rwanda (11) and Burundi (21). 
Table 2. Average efficient results

\begin{tabular}{llcclllllllllll}
\hline & \multicolumn{1}{c}{2008} & \multicolumn{3}{c}{2009} & & & 2010 & \multicolumn{5}{c}{2011} \\
\hline EAC count & CRS & VRS & S E & CRS & VRS & SE & CRS & VRS & SE & CRS & VRS & SE TOT \\
TZ (Avg) & 0.738 & 0.784 & 0.944 & 0.508 & 0.7 & 0.76 & 0.677 & 0.811 & 0.839 & 0.656 & 0.743 & 0.885 & \\
Eff DMU & 5 & 6 & 5 & 1 & 4 & 1 & 2 & 4 & 2 & 3 & 6 & 3 & 42 \\
KNY(Avg) & 0.891 & 0.94 & 0.944 & 0.556 & 0.619 & 0.901 & 0.78 & 0.817 & 0.953 & 0.836 & 0.84 & 0.996 & \\
Eff DM & 10 & 10 & 10 & 1 & 1 & 1 & 4 & 4 & 4 & 7 & 7 & 7 & 66 \\
UGNAvg) & 0.791 & 0.855 & 0.918 & 0.704 & 0.899 & 0.789 & 0.742 & 0.939 & 0.786 & 0.749 & 0.955 & 0.784 & \\
Eff DMU & 5 & 5 & 5 & 4 & 7 & 4 & 3 & 8 & 3 & 4 & 9 & 4 & 61 \\
RND(Avg) & 0.901 & 0.926 & 0.972 & 0.431 & 0.49 & 0.884 & 0.673 & 0.699 & 0.966 & 0.599 & 0.662 & 0.93 & \\
Eff DMU & 3 & 3 & 3 & 0 & 0 & 0 & 0 & 1 & 0 & 0 & 1 & 0 & 11 \\
BRD(Avg) & 0.819 & 0.832 & 0.985 & 0.705 & 0.713 & 0.985 & 0.789 & 0.793 & 0.993 & 0.817 & 0.817 & 0.999 & \\
Eff DMU & 2 & 2 & 2 & 2 & 2 & 2 & 2 & 2 & 2 & 1 & 1 & 1 & 21 \\
\hline
\end{tabular}

Note: $\mathrm{TZ}=$ Tanzania, KNY=Kenya, UGN=Uganda, RND=Rwanda, BRD=Burundi, Eff DMU=Efficient DMU, $\mathrm{EAC}=$ East African Countries

\section{Conclusion}

This paper employs Data Envelopment analysis (DEA) To estimate the relative efficiency of selected 58 commercial banks operating within the African Community, namely Tanzania, Kenya, Uganda, Rwanda and Burundi (From 2008 to 2011).The estimated results shows sharp decline of Technical efficiency from 0.81 (2008) to 0.56 (2009) there after showing an increasing trend of technical efficiency in 0.73 (2011). Under BCC and CCR model the number of efficient commercial banks which shows in their four years with the score 1, were Tanzania (42), Kenya (66), Uganda (61), Rwanda (11) and Burundi (21). The findings show that most commercial banks in east Africa are operating under a decreasing return to scale. These findings are quite similar to Sathye, M, M (2011) whose empirical investigation in Australian commercial banks using similar method found low efficiency level compared to banks in European countries, the major cause of efficiency was attributed to wasting of inputs (technical inefficiency rather than choosing of the correct input combination allocative efficiency as well as Singh (2010) whose results found that the main sources of inefficiency amongst 300 banks are dominated by ineffective utilization of resources rather than economies of scale. Therefore inefficient utilization of input resources could be one of the reasons for inefficiency; therefore banks should make use of underutilized resources which can enhance production of different outputs.

We recommend commercial banks to minimize the use of input resources while maintaining the same level of output. By improving handling of operating expenses, advances, capital and by boosting banking investment operation, the less efficient banks can successfully endorse resource utilization efficiency. However the results of this analysis have important implications for management of the banks, policy makers and bank regulators in East Africa. Future research should be concerned with factors influencing the efficiency of East African commercial banks. Moreover the study of banks heterogeneity can provide more precise comparative analysis of commercial banks operating in East Africa.

\section{References}

Aikaeli, J. (2008). Commercial bank efficiency in Tanzania. A paper presented at a CSAE Conference on -Economic Development in Africa, held at St. Catherine's College, Oxford, $16^{\text {th }}-18^{\text {th }}$.

Alin, M., \& Vasile, M. (2010). Comparative analysis of Efficiency of Romanian Banks. Romanian Journal of Economic forecasting, 4.

Allen, L., \& Rai. (1996). Operational efficiency in banking: an intermediation comparison. Journal of Banking and Finance, 20, 655-672. http://dx.doi.org/10.1016/0378-4266(95)00026-7

Barr, R. S., Seiford, L. M., \& Siems, T. (1994). Forecasting Bank Failure: A Non- Parametric Frontier Estimation Approach. Recherches Economiques De Louvain, 60, 417-29.

Barr, R. S., Seiford, L. M., \& Siems, T. F. (1993). An Envelopment-analytical approach to measuring the managerial efficiency of banks. Third European Workshop on efficiency and productivity measurement, 
center for operational research and econometric, Louvain, Belgium (October).

Bauer et al. (1998). Consistency conditions for regulatory analysis of financial institutions: comparison of frontier methods. Journal of Business and finance, 50, 85-114.

Berger, A. N., \& Humphrey, D. B. (1997). Efficiency of financial institutions: International survey directions for future research. European Journal of Operational Research, 98, 175-212. http://dx.doi.org/10.1016/S0377-2217(96)00342-6

Berger, A. N., Hunter, W. C., \& Timme, S. G. (1993). Efficiency of financial institutions: A review and preview of research, past present, and the future. Journal of banking and finance, 21, 895-947. http://dx.doi.org/10.1016/S0378-4266(97)00010-1

Charnes, A., \& Cooper, W. E. (1978). Measuring efficiency of decision making units. European Journal of operational Research, 429-444. http://dx.doi.org/10.1016/0377-2217(78)90138-8

Debreu. (1951). The coefficient of resource utilization. Econometrica, 273-92. http://dx.doi.org/10.2307/1906814

Drake, L. (2003). Costs and efficiency in banking: A survey of the evidence from the US, the UK and Japan. In A.W. Mullineux and V.Murinde (Eds.), Handbook of International banking (Cheltenham: Edward Elger).

Drake, L., \& Hall, M. J. B. (2003). Efficiency in Japanese banking: an empirical analysis. Journal of Banking and Finance, 27, 891-917. http://dx.doi.org/10.1016/S0378-4266(02)00240-6

Farrell, M. J. (1957). the measurement of productive efficiency. Journal of royal statistical society series, 253-81. http://dx.doi.org/10.2307/2343100

Ferrier, G., \& Lovell, C. A. K. (1990). Measuring cost efficiency in banking: Econometric and linear $\begin{array}{llll}\text { programming } & \text { evidence. Journal of Econometrics, } 46,245 .\end{array}$ http://dx.doi.org/10.1016/0304-4076(90)90057-Z

Fries., \& Taci, A. (2005). Cost Efficiency of Banks in Transition: Evidence from 289 Banks Post communist countries. Journal of banking and finance, 29, 55-58. http://dx.doi.org/10.1016/j.jbankfin.2004.06.016

Hassan, T. (2009). Efficiency of convectional versus from Islamic banks: Evidence from Middle East. International Journal of Islamic and Middle Eastern Finance Management, 2(1), 46-65. http://dx.doi.org/10.1108/17538390910946267

Ikhide, S. I. (2008). Measuring operational efficiency of commercial banks in Namibia. South African Journal of economics, 76(4), 586-95. http://dx.doi.org/10.1111/j.1813-6982.2008.00214.x

IMF. (2010). Country report 10/177 Financial system stability assessment report.

IMF. (2012). Working paper (WP/12/32) Assessing bank competition with the East African community.

Kamau, A. W. (2011). Intermediation efficiency and productivity of the banking sector in Kenya. Interdisciplinary Journal of Research in Business, 1(9), 12-26.

Kiyota. (2009). Efficiency of commercial banks in Sub Sahara: A comparative analysis Domestic and Foreign bank. Paper presented at the CSAE conference 2009 on "Economic Development in Africa".

Molyneux, P., \& Thornton, J. (1992). Determinants of European bank profitability: a note. Journal of Banking and Finance, 16, 1173-1178. http://dx.doi.org/10.1016/0378-4266(92)90065-8

Musonda. (2008). An investigation into the determination of cost efficiency in the Zambian Banking system. Paper presented at the 13h Annual African Econometrics Society (AES) conference, South Africa.

Ncube. (2009). Efficiency of banking sector in South Africa. African Economic conference, Addis Ababa-Ethiopia.

Ngalande, E. (2003). The importance of financial system modernization in Africa. keynote address at the peer user group conference, BIS Review 27 South Africa.

Noulas, A, G. (1997). Productivity growth in the Hellenic banking Industry: State versus private banks. Applied financial Economics, 7, 223-228. http://dx.doi.org/10.1080/096031097333574

Samy, B. N., Hichen, B. K., \& Barbara, C. (2009). What drives efficiency of selected MENA banks? A Meta frontier analysis WP03/09 Cass business school.

Sathye, M. (2001). X-efficiency in Australian Banking: An empirical investigation. Journal of banking and Finance, 25, 613-630. http://dx.doi.org/10.1016/S0378-4266(00)00156-4 
Sathye, M. (2000). Efficiency of Banks in a Developing Economy: The Case of India. School of Accounting, Banking and Finance, University of Canberra, Canberra.

Sealey, C., \& Lindley, J. (1997). Inputs and outputs, and Theory of production and cost at depository financial institutions. Journal of finance, 32(4).

Siems, T. F. (1992). Quantifying Management's role in bank survival. Federal Reserve bank of Dallas, Economic Review (January), 29-41.

Singh. (2008). A Cross country comparison of banking efficiency: Asian Pacific Banks. International Review of business research papers, 4(3), 73-95.

Sobudu et al. (1998). Bank performance and supervision in Nigeria: Analysis the transition to a deregulated economy. MIC Research Consortium Nairobi.

Tulkens, H. (1993). On FDH efficiency Analysis: Some methodological issue and applications to retail banking, Courts and Urban Transit. Journal of Productivity Analysis. http://dx.doi.org/10.1007/BF01073473

Victor, M., \& Mosses, T. (2002). A foreign affair? How far does Africa need a foreign bank? march 2002 Insight issue No 40 communicating development research.

Yue, P. (1992). Data Envelopment Analysis and Commercial bank performance: A primer with application to Missouri banks. Federal Reserve Bank of St. Louis Review, 74, 31-45.

\section{Appendix}

Appendix 1. Descriptive statistics of variables used

\begin{tabular}{lllllll}
\hline Country & Variable & Obs & Mean & Std. Dev. & Min & Max \\
\hline \multirow{6}{*}{ Kenya } & DEPO & 63 & $4.55 \mathrm{E}+10$ & $4.25 \mathrm{E}+10$ & $5.91 \mathrm{E}+07$ & $1.63 \mathrm{E}+11$ \\
& INEX & 63 & $1.46 \mathrm{E}+09$ & $9.93 \mathrm{E}+08$ & 269.2 & $3.81 \mathrm{E}+09$ \\
& OPEX & 63 & $3.65 \mathrm{E}+09$ & $4.32 \mathrm{E}+09$ & 266000 & $1.48 \mathrm{E}+10$ \\
& LOAN & 63 & $3.60 \mathrm{E}+10$ & $3.50 \mathrm{E}+10$ & 4110400 & $1.37 \mathrm{E}+11$ \\
& INVEST & 63 & $1.35 \mathrm{E}+10$ & $1.62 \mathrm{E}+10$ & $4.62 \mathrm{E}+07$ & $6.06 \mathrm{E}+10$ \\
& INTI & 63 & $1.38 \mathrm{E}+09$ & $3.74 \mathrm{E}+09$ & 265276 & $1.63 \mathrm{E}+10$ \\
& NII & 63 & $1.97 \mathrm{E}+09$ & $2.69 \mathrm{E}+09$ & 130700 & $1.04 \mathrm{E}+10$ \\
& DEPO & 43 & $5.02 \mathrm{E}+11$ & $4.91 \mathrm{E}+11$ & $1.60 \mathrm{E}+08$ & $1.90 \mathrm{E}+12$ \\
& INEX & 43 & $1.61 \mathrm{E}+10$ & $1.41 \mathrm{E}+10$ & 0 & $5.46 \mathrm{E}+10$ \\
& OPEX & 43 & $3.30 \mathrm{E}+10$ & $3.83 \mathrm{E}+10$ & $1.69 \mathrm{E}+07$ & $1.25 \mathrm{E}+11$ \\
& LOAN & 43 & $2.97 \mathrm{E}+11$ & $4.00 \mathrm{E}+11$ & $4.72 \mathrm{E}+07$ & $1.53 \mathrm{E}+12$ \\
& INVEST & 43 & $1.15 \mathrm{E}+11$ & $1.44 \mathrm{E}+11$ & 0 & $4.60 \mathrm{E}+11$ \\
& INTI & 43 & $6.60 \mathrm{E}+10$ & $6.53 \mathrm{E}+10$ & $2.38 \mathrm{E}+07$ & $3.00 \mathrm{E}+11$ \\
Uganda & NII & 43 & $2.79 \mathrm{E}+10$ & $2.76 \mathrm{E}+10$ & 4680800 & $9.53 \mathrm{E}+10$ \\
& DEPO & 80 & $3.69 \mathrm{E}+11$ & $5.24 \mathrm{E}+11$ & $2.74 \mathrm{E}+09$ & $2.41 \mathrm{E}+12$ \\
& INEX & 80 & $9.95 \mathrm{E}+09$ & $2.22 \mathrm{E}+10$ & $2.70 \mathrm{E}+07$ & $1.92 \mathrm{E}+11$ \\
& OPEX & 80 & $2.57 \mathrm{E}+10$ & $3.54 \mathrm{E}+10$ & $8.58 \mathrm{E}+07$ & $1.52 \mathrm{E}+11$ \\
& LOAN & 80 & $2.10 \mathrm{E}+11$ & $3.04 \mathrm{E}+11$ & $5.07 \mathrm{E}+08$ & $1.43 \mathrm{E}+12$ \\
& INVEST & 80 & $7.69 \mathrm{E}+10$ & $1.31 \mathrm{E}+11$ & 0 & $6.31 \mathrm{E}+11$ \\
& INTI & 80 & $3.23 \mathrm{E}+10$ & $4.44 \mathrm{E}+10$ & $9.32 \mathrm{E}+07$ & $1.85 \mathrm{E}+11$ \\
Tanzania & NII & 80 & $1.59 \mathrm{E}+10$ & $2.65 \mathrm{E}+10$ & 0 & $1.92 \mathrm{E}+11$ \\
& DEPO & 26 & $8.42 \mathrm{E}+10$ & $6.83 \mathrm{E}+10$ & $1.14 \mathrm{E}+08$ & $2.93 \mathrm{E}+11$ \\
& INEX & 26 & $3.78 \mathrm{E}+09$ & $9.85 \mathrm{E}+09$ & 0 & $5.09 \mathrm{E}+10$ \\
& OPEX & 26 & $6.94 \mathrm{E}+09$ & $5.42 \mathrm{E}+09$ & 0 & $1.93 \mathrm{E}+10$ \\
& LOAN & 26 & $5.12 \mathrm{E}+10$ & $3.65 \mathrm{E}+10$ & 0 & $1.27 \mathrm{E}+11$ \\
& INVEST & 26 & $1.11 \mathrm{E}+10$ & $2.90 \mathrm{E}+10$ & 0 & $1.49 \mathrm{E}+11$ \\
& INTI & 26 & $7.88 \mathrm{E}+09$ & $6.30 \mathrm{E}+09$ & 1800000 & $2.62 \mathrm{E}+10$ \\
\hline
\end{tabular}




\begin{tabular}{lllllll}
\hline Rwanda & NII & 26 & $4.45 \mathrm{E}+09$ & $7.39 \mathrm{E}+09$ & 1100000 & $3.65 \mathrm{E}+10$ \\
& DEPO & 19 & $6.60 \mathrm{E}+10$ & $7.70 \mathrm{E}+10$ & $1.79 \mathrm{E}+09$ & $2.44 \mathrm{E}+11$ \\
& INEX & 19 & $1.30 \mathrm{E}+09$ & $8.69 \mathrm{E}+08$ & $2.29 \mathrm{E}+08$ & $3.56 \mathrm{E}+09$ \\
& OPEX & 19 & $5.16 \mathrm{E}+09$ & $4.16 \mathrm{E}+09$ & $6.32 \mathrm{E}+08$ & $1.32 \mathrm{E}+10$ \\
& LOAN & 19 & $3.75 \mathrm{E}+10$ & $3.20 \mathrm{E}+10$ & $9.84 \mathrm{E}+09$ & $1.27 \mathrm{E}+11$ \\
& INVEST & 19 & $8.72 \mathrm{E}+09$ & $1.03 \mathrm{E}+10$ & 0 & $2.95 \mathrm{E}+10$ \\
& INTI & 19 & $4.34 \mathrm{E}+09$ & $3.32 \mathrm{E}+09$ & $1.39 \mathrm{E}+09$ & $1.35 \mathrm{E}+10$ \\
Burundi & NNI & 19 & $4.37 \mathrm{E}+09$ & $4.37 \mathrm{E}+09$ & $2.02 \mathrm{E}+07$ & $1.32 \mathrm{E}+10$ \\
\hline
\end{tabular}

Note: Inputs are (NNI) Non interest income, (DEPO) deposit, (INEX) Interest expenses; (OPEX) operating expenses while the outputs are (INVEST) Investment, (INTI) interest income and (NII) noninterest income.

Appendix 2. Input- oriented CRS efficiency estimates

\begin{tabular}{|c|c|c|c|c|c|c|}
\hline \multirow[b]{2}{*}{ DMU no } & \multirow[b]{2}{*}{ Country } & \multirow[b]{2}{*}{ DMU name } & \multicolumn{3}{|c|}{ Input- oriented CRS Efficiency } & \multirow[b]{2}{*}{2011} \\
\hline & & & 2008 & 2009 & 2010 & \\
\hline 1 & & ENDES & 1 & 1 & 1 & 1 \\
\hline 2 & & $\mathrm{BCB}$ & 0.922649 & 0.515401 & 0.6276 & 0.826504 \\
\hline 3 & & $\mathrm{BOC}$ & 1 & 1 & 1 & 0.810982 \\
\hline 4 & & ECO & 0.497267 & 0.553385 & 0.875187 & 0.902322 \\
\hline 5 & Burundi & GBGF & 0.677016 & 0.454726 & 0.440176 & 0.543322 \\
\hline 6 & & DBK & 1 & 0.870778 & 0.861569 & 0.97064 \\
\hline 7 & & NIC & 1 & 0.429038 & 1 & 0.905664 \\
\hline 8 & & $\mathrm{ABC}$ & 0.638114 & 0.453519 & 0.773012 & 1 \\
\hline 9 & & BBK & 1 & 0.663406 & 1 & 1 \\
\hline 10 & & DTB & 0.895411 & 0.383065 & 0.630611 & 0.653026 \\
\hline 11 & & ECO & 1 & 0.484633 & 0.925453 & 0.722114 \\
\hline 12 & & EQB & 1 & 0.487892 & 0.682011 & 1 \\
\hline 13 & & FINA & 0.823308 & 0.387846 & 0.377195 & 0.50171 \\
\hline 14 & & IMB & 1 & 0.414137 & 0.84545 & 0.76084 \\
\hline 15 & & IMP & 0.785089 & 0.374134 & 0.587797 & 0.47862 \\
\hline 16 & & $\mathrm{KCB}$ & 1 & 0.474298 & 0.666103 & 0.778675 \\
\hline 17 & & NBK & 1 & 0.742701 & 0.69251 & 1 \\
\hline 18 & & $\mathrm{SCB}$ & 1 & 1 & 1 & 1 \\
\hline 19 & & STANBIC & 1 & 0.60864 & 0.711462 & 0.612324 \\
\hline 20 & & TNB & 0.596514 & 0.661439 & 1 & 1 \\
\hline 21 & Kenya & VCB & 0.521767 & 0.46022 & 0.734471 & 1 \\
\hline 22 & & ACCESS & 0.730775 & 0.344294 & 0.726312 & 0.455862 \\
\hline 23 & & BANCOM & 0.846396 & 0.320474 & 0.587453 & 0.511861 \\
\hline 24 & & BANCPOP & 1 & 0.559949 & 0.942639 & 0.849677 \\
\hline 25 & & BOK & 0.831101 & 0.548731 & 0.798949 & 0.618767 \\
\hline 26 & & ECO & 1 & 0.338607 & 0.51214 & 0.481476 \\
\hline 27 & Rwanda & $\mathrm{KCB}$ & 1 & 0.476899 & 0.472821 & 0.679112 \\
\hline 28 & & $\mathrm{BOA}$ & 0.470483 & 0.359408 & 0.550561 & 0.469433 \\
\hline
\end{tabular}




\begin{tabular}{|c|c|c|c|c|c|c|}
\hline 29 & & TZ ACB & 0.527014 & 0.446761 & 0.711342 & 0.784151 \\
\hline 30 & & TZ ACCESS & 0.880552 & 0.411121 & 0.526029 & 0.37634 \\
\hline 31 & & AZANIA & 0.452473 & 0.449215 & 0.501678 & 0.310182 \\
\hline 32 & & BANK M & 0.535591 & 0.54035 & 0.721335 & 0.65279 \\
\hline 33 & & BARCLAYS & 0.441504 & 0.433671 & 0.567144 & 0.23351 \\
\hline 34 & & BOB & 0.804444 & 0.356278 & 0.614174 & 0.832533 \\
\hline 35 & & CBA & 0.761686 & 0.584688 & 0.65038 & 0.486357 \\
\hline 36 & & CITIBANK & 0.917062 & 0.96292 & 1 & 1 \\
\hline 37 & & CRDB & 0.689765 & 0.404598 & 0.643133 & 0.728436 \\
\hline 38 & & EXIM & 0.564614 & 0.47829 & 0.644501 & 0.529435 \\
\hline 39 & & FBME & 0.514324 & 0.382593 & 0.418152 & 0.373929 \\
\hline 40 & & I\&M & 0.674695 & 0.431588 & 0.761848 & 0.991528 \\
\hline 41 & & ICB & 1 & 0.484438 & 1 & 1 \\
\hline 42 & & $\mathrm{KCB}$ & 0.544443 & 0.503263 & 0.502526 & 0.605231 \\
\hline 43 & & NBC & 1 & 0.501186 & 0.665033 & 0.56326 \\
\hline 44 & & NIC & 1 & 1 & 0.741881 & 0.690798 \\
\hline 45 & & NMB & 1 & 0.557592 & 0.795054 & 0.895177 \\
\hline 46 & & PBZ & 1 & 0.435425 & 0.65251 & 1 \\
\hline 47 & Tanzania & STANBIC & 0.977033 & 0.442615 & 0.865355 & 0.593428 \\
\hline 48 & & CENT & 0.753701 & 0.528004 & 0.654506 & 0.584629 \\
\hline 49 & & $\mathrm{SBC}$ & 1 & 1 & 1 & 1 \\
\hline 50 & & BARCLAYS & 0.513862 & 0.507687 & 0.556578 & 0.561446 \\
\hline 51 & & $\mathrm{BOA}$ & 0.625504 & 0.475162 & 0.532249 & 0.515044 \\
\hline 52 & & BOB & 1 & 0.593116 & 1 & 1 \\
\hline 53 & & CITIBANK & 1 & 1 & 0.881625 & 0.811364 \\
\hline 54 & & CRANE & 0.392095 & 0.455159 & 0.684564 & 0.568845 \\
\hline 55 & & DTB & 0.568631 & 0.33055 & 0.377494 & 1 \\
\hline 56 & & IQUI & 1 & 1 & 0.575817 & 0.514171 \\
\hline 57 & & $\mathrm{KCB}$ & 1 & 1 & 1 & 1 \\
\hline 58 & Uganda & $\mathrm{SCB}$ & 0.843835 & 0.859339 & 0.901674 & 0.685168 \\
\hline \multicolumn{3}{|c|}{ Mean efficiency } & 0.8141158 & 0.5676419 & 0.7270356 & 0.7313911 \\
\hline
\end{tabular}

Appendix 3. Input- oriented VRS efficiency estimates

\begin{tabular}{|c|c|c|c|c|c|c|}
\hline \multirow[b]{2}{*}{ DMU no } & \multirow[b]{2}{*}{ Country } & \multirow[b]{2}{*}{ DMU name } & \multicolumn{3}{|c|}{ Input- oriented VRS Efficiency } & \multirow[b]{2}{*}{2011} \\
\hline & & & 2008 & 2009 & 2010 & \\
\hline 1 & & ENDES & 1 & 1 & 1 & 1 \\
\hline 2 & & $\mathrm{BCB}$ & 0.972639 & 0.531993 & 0.647532 & 0.826506 \\
\hline 3 & & $\mathrm{BOC}$ & 1 & 1 & 1 & 0.811005 \\
\hline 4 & & ECO & 0.501573 & 0.574931 & 0.875806 & 0.902466 \\
\hline 5 & Burundi & GBGF & 0.685602 & 0.456743 & 0.442247 & 0.544635 \\
\hline 6 & & DBK & 1 & 0.910595 & 0.890221 & 0.9784 \\
\hline 7 & & NIC & 1 & 0.553243 & 1 & 0.90629 \\
\hline
\end{tabular}




\begin{tabular}{|c|c|c|c|c|c|c|}
\hline 8 & & $\mathrm{ABC}$ & 0.752573 & 0.466264 & 0.792528 & 1 \\
\hline 9 & & BBK & 1 & 0.726021 & 1 & 1 \\
\hline 10 & & DTB & 0.916244 & 0.526088 & 0.760968 & 0.653243 \\
\hline 11 & & $\mathrm{ECO}$ & 1 & 0.491103 & 0.929796 & 0.723467 \\
\hline 12 & & EQB & 1 & 0.742802 & 0.844807 & 1 \\
\hline 13 & & FINA & 0.850407 & 0.391788 & 0.383019 & 0.502197 \\
\hline 14 & & IMB & 1 & 0.414318 & 0.853935 & 0.761151 \\
\hline 15 & & IMP & 0.841166 & 0.378332 & 0.591947 & 0.47962 \\
\hline 16 & & $\mathrm{KCB}$ & 1 & 0.664694 & 0.763842 & 0.816665 \\
\hline 17 & & NBK & 1 & 0.744731 & 0.713814 & 1 \\
\hline 18 & & SCB & 1 & 1 & 1 & 1 \\
\hline 19 & & STANBIC & 1 & 0.686057 & 0.785563 & 0.612351 \\
\hline 20 & & TNB & 0.711947 & 0.713048 & 1 & 1 \\
\hline 21 & Kenya & $\mathrm{VCB}$ & 0.960054 & 0.497574 & 0.766043 & 1 \\
\hline 22 & & ACCESS & 0.76735 & 0.34468 & 0.726333 & 0.456346 \\
\hline 23 & & BANCOM & 0.852183 & 0.399547 & 0.589853 & 0.51213 \\
\hline 24 & & BANCPOP & 1 & 0.666707 & 1 & 1 \\
\hline 25 & & $\mathrm{BOK}$ & 0.937644 & 0.616196 & 0.844632 & 0.841651 \\
\hline 26 & & ECO & 1 & 0.406421 & 0.559168 & 0.481884 \\
\hline 27 & Rwanda & $\mathrm{KCB}$ & 1 & 0.508294 & 0.476269 & 0.679148 \\
\hline 28 & & BOA & 0.475068 & 0.414391 & 0.603852 & 0.498503 \\
\hline 29 & & $\mathrm{TZ} \mathrm{ACB}$ & 0.527517 & 0.509647 & 0.914842 & 0.854039 \\
\hline 30 & & TZ ACCESS & 0.902488 & 0.430776 & 0.861247 & 0.389674 \\
\hline 31 & & AZANIA & 0.454204 & 0.863039 & 0.797841 & 0.310654 \\
\hline 32 & & BANK M & 0.537932 & 0.798171 & 0.823395 & 0.704241 \\
\hline 33 & & BARCLAYS & 0.662812 & 0.740465 & 0.851094 & 0.325659 \\
\hline 34 & & BOB & 0.839978 & 0.372114 & 0.615163 & 0.84878 \\
\hline 35 & & CBA & 0.768199 & 0.627663 & 0.796315 & 0.580162 \\
\hline 36 & & CITIBANK & 0.955959 & 1 & 1 & 1 \\
\hline 37 & & CRDB & 1 & 1 & 0.775774 & 1 \\
\hline 38 & & EXIM & 0.801904 & 0.751872 & 0.782256 & 0.808563 \\
\hline 39 & & FBME & 0.518724 & 0.657503 & 0.445084 & 0.385008 \\
\hline 40 & & $\mathrm{I} \& \mathrm{M}$ & 0.683753 & 0.518556 & 0.880654 & 1 \\
\hline 41 & & INT'NAL CB & 1 & 0.485944 & 1 & 1 \\
\hline 42 & & $\mathrm{KCB}$ & 0.544565 & 0.701513 & 0.625337 & 0.730901 \\
\hline 43 & & NBC & 1 & 0.969556 & 0.95655 & 0.895377 \\
\hline 44 & & NIC & 1 & 1 & 0.74945 & 0.690899 \\
\hline 45 & & NMB & 1 & 1 & 1 & 1 \\
\hline 46 & & PBZ & 1 & 0.435968 & 0.736744 & 1 \\
\hline 47 & Tanzania & STANBIC & 1 & 0.717983 & 1 & 0.829821 \\
\hline 48 & & CENT & 0.839621 & 1 & 1 & 1 \\
\hline 49 & & $\mathrm{SBC}$ & 1 & 1 & 1 & 1 \\
\hline
\end{tabular}




\begin{tabular}{|c|c|c|c|c|c|c|}
\hline 50 & & BARCLAYS & 0.858357 & 0.703322 & 0.993236 & 1 \\
\hline 51 & & $\mathrm{BOA}$ & 0.663444 & 1 & 1 & 0.61678 \\
\hline 52 & & BOB & 1 & 1 & 1 & 1 \\
\hline 53 & & CITIBANK & 1 & 1 & 1 & 1 \\
\hline 54 & & CRANE & 0.479294 & 0.847204 & 1 & 1 \\
\hline 55 & & DTB & 0.568947 & 0.34228 & 0.523684 & 1 \\
\hline 56 & & IQUI & 1 & 1 & 0.814258 & 0.883477 \\
\hline 57 & & $\mathrm{KCB}$ & 1 & 1 & 1 & 1 \\
\hline 58 & Uganda & $\mathrm{SCB}$ & 1 & 1 & 1 & 1 \\
\hline \multicolumn{3}{|c|}{ Mean efficiency } & 0.859174966 & 0.694829948 & 0.823881017 & 0.807615397 \\
\hline
\end{tabular}

